Title:

The export additionality of innovation policy

Co-Authors*

Mark Freel

Telfer School of Management, University of Ottawa

55 Laurier East

Ottawa, ON KIN 6N5, Canada

Email: freel@telfer.uottawa.ca

and

Lancaster University Management School

Balilrigg

Lancaster, LA1 4YX, UK

Rebecca Liu (Corresponding author)

Lancaster University Management School

Bailrigg

Lancaster, LA1 4YX, UK

Email: rebecca.liu@lancaster.ac.uk

\title{
Christian Rammer
}

Department of Industrial Economics and International Management, ZEW

L7, 1; D-68161 Mannheim, Germany

Email: christian.rammer@zew.de

*Three co-authors are listed in alphabetical order with equal contributions.

The corresponding author is Rebecca Liu. 
Title:

The export additionality of innovation policy

\begin{abstract}
The empirical evidence that innovation policies often lead to innovation additionality is longstanding. However, innovation is an intermediate outcome. Innovations are important to the extent that they contribute to some broader goal, such as the competitiveness of firms and economies. To this end, we take exporting as an important indicator of competitiveness and investigate whether innovation interventions lead to exporting outcomes. Using the Mannheim Innovation Panel, the current study explores whether innovation interventions at various administrative levels associate with changing export behaviours among German SMEs. Our results provide evidence of the scope for policymakers to employ innovation interventions as export policy.
\end{abstract}

Keywords: innovation policy; exporting; additionality; SMEs 


\section{Introduction}

The notion that innovation and exporting are positively associated is firmly entrenched in the empirical literature. Whether it is as innovation driving the decision to export (e.g. Wakelin 1998; Basile 2001; Roper and Love 2002; Cassiman et al. 2010) or, more occasionally, exporting inducing innovation through international learning (Alvarez and Robertson 2004; Salomon and Shaver 2005; Love and Ganotakis 2013; Fassio 2017), the evidence for a positive association is both longstanding and abundant. Moreover, recent empirical work (e.g. Bogliacino et al., 2017) has identified a "virtuous circle", with export markets driving the success of new products and providing the resources for further innovation. Indeed, Ito and Lechevalier (2010), for instance, suggest that the interplay of innovation and exporting is an important source of permanent differences in the performance of firms (see also Filatotchev and Piesse 2009).

However, there is some suggestion that this complementarity may be lower in small firms, as resource constraints compel managers to pick between two high risk strategies (Kiss et al. 2018). This is the choice to "focus on product development specifically for the home market or allocate fewer resources to innovation and more to developing new export markets" (Roper and Love 2002, p. 1096). Yet, more recent evidence suggests that innovation and exporting appear to operate jointly to improve performance even in small firms (Love and Roper 2015), in such a way that innovation in the absence of foreign market access does not lead to significant performance enhancement. Or, in reverse, exposing small firms to export markets will not lead to productivity improvements if not complemented by firm-level innovation efforts (Golovko and Valentini 2011).

Importantly, the general relationship between innovation (and product innovation in particular) and export performance is liable to be more apparent in smaller firms. Large firms are likely to already be 
active in international markets (Cassiman and Golovko 2011). They are also likely to be engaged in innovation (Cohen 2010). Moreover, the international activities of large firms are typically multifaceted, while exporting remains the preferred initial method of internationalising in SMEs (Golovko and Valentini 2011). Recognition of the peculiarities of large firms has resulted in a shift towards SMEs as the primary targets of innovation and export promotion policies in Europe (McCann and Ortega-Argilés 2016) ${ }^{1}$. SMEs are also the focus of the current study.

Despite the apparent complementarity of innovation and exporting, polices to promote either typically operate discretely. Both feature prominently in the industrial policy catalogues of most countries. Yet, innovation policies are invariably concerned solely with innovation additionality - with the extent to which the specific policy instrument induces innovation (Cannone and Ughetto 2014). Most frequently this is a focus on output (e.g. new product introduction) or input (e.g. R\&D) additionality. Rarely is the concern with behavioural additionality (Clarysse et al. 2009). Behavioural additionality is a second order additionality (Autio et al. 2008) conceived of as the difference in firm behaviour resulting from the intervention (Georghiou 1998). Exporting may be an important behavioural additionality of innovation policy. Many smaller firms are neither clearly exporters nor non-exporters. Rather, they exist in a world "in which opportunistic, intermittent and even accidental exporting are commonplace" (Bernini et al, 2016, p. 1072). If innovation policies can be shown to shift such firms to more persistent patterns of exporting this would constitute a significant behavioural additionality. Similarly, shifting small firms from non-exporting to exporting or from limited exporting to intensive exporting may also constitute important behavioural additionalities. This is our interest here.

\footnotetext{
${ }^{1}$ In large part under the framework of 'smart specialisation'.
} 
Specifically, we investigate the effects of the additional innovation that results from public innovation interventions on the subsequent export behaviour of German SMEs. The German Innovation Survey provides additional data that are not part of the harmonised questionnaire of the Community Innovation Survey (CIS); such as export sales volume, labour and material costs and capital stock (Peters and Rammer, 2013). These non-CIS data are unique and important for this study. For the purposes of this study, the panel was constrained to range from 2001 to 2014. Germany provides an important case study of SME support policies for its relatively broad range of funding schemes that have been implemented over many years.

Our analysis of the extent to which policy induced innovation influences export behaviour is undertaken in two steps: 1. Estimating the innovation additionality resulting from policy support (reported in the appendices to the paper); and, 2. Assessing the extent to which any additional innovation leads to changing export behaviour. Moreover, in both steps we distinguish between 4 'levels' of policy provision (regional, national bottom-up, national technology programmes, and EU). This allows the study to contribute to knowledge in two important ways: First, the study assesses the extent to which innovation policies lead to exporting outcomes in SMEs. This concern is in line with recognition of innovation as 'only' an intermediate outcome of policy, and of the suggested scope for innovation policies to foster exporting, and it contributes to discussions in support of coordinated innovation and exporting policies for SMEs (Love and Roper 2015). Secondly, we are able to disentangle the exporting impacts associated with public support delivered by different administrative levels, acting with different priorities. To the extent that policies administered by different levels of government are likely to be driven by different policy concerns, this is an important step in understanding the scope for indirect export promotion. More generally, it calls for attention to heterogeneous programme characteristics in the evaluation of funding policy. 
The article is structured as follows. Section two summarises a review of relevant literature and outlines research objectives. Section three presents the institutional background with an overview of the public funding schemes for SME innovations in Germany. Section four reports the research method, followed by a discussion of empirical results in Section five. Section six concludes this article by summarising the implications for theory and practice, the limitations of the study and suggestions for further research.

\section{Literature}

\subsection{Linking Innovating and exporting}

As noted, there is ample empirical evidence linking innovation and exporting. A smaller part of this is concerned with the extent to which exporting induces innovation in firms. This is the notion that export markets may provide access to novel information and technology which may be used to spur future innovation activity (Golovko and Valentini 2011) or, that extending the markets over which margins may be earned aids productivity and provides greater incentives to invest in innovation (Ganotakis and Love 2012). Fassio (2017) identifies these as technology learning and foreign demand effects, respectively. However, evidence for the 'learning by exporting' hypotheses is relatively slight. Where there is evidence in favour of a 'learning by exporting' effect it is typically found in developing economies (Martins and Yang 2009) or in technology lagging industries (Salomon and Jin 2008).

For developed economies and in most industries, convention holds that prior decisions regarding innovation explain future exporting activity (Damijan et al. 2010). This is usually explained either through a direct demand expansion effect or through an indirect productivity effect (Cassiman and Golovko 2011; Aw et al. 2011). The former case is commonly traced to Vernon's (1966, p. 191) early work on the role of 
"innovation, scale, ignorance and uncertainty" in explaining patterns of internationalisation at the firm level. Vernon's (1966) theory is concerned with product lifecycles: Firms innovate in response to opportunities in their home markets. However, as demand for the product begins to appear in other places, firms internationalise initially through exporting. This is about the search for greater demand for new products or the need to spread R\&D costs over a greater volume of sales (Cassiman et al. 2010). On the other hand, the indirect path from innovation to exporting leads through productivity. Exporting firms are invariably shown to record higher productivity levels prior to exporting than non-exporting firms (Damijan et al. 2010). Past research has shown that much of the difference in productivity between firms may derive from differential investments in R\&D (Parisi et al. 2006) and innovation outputs (Crépon et al. 1998), and that these observations hold for SMEs (Hall et al. 2009).

Together these mirror the two main conceptual approaches used to modelling the determinants of export performance: Neo-endowment models that identify competitive advantages grounded in factor endowments; and, technology-based models in which competitive advantage is derived from the quality of firms' products and services (Ganotakis and Love 2011; Love and Ganotakis 2013). Both imply a causal link from innovation to exporting.

Yet, the different explanations imply different roles for product and process innovation. And the empirical evidence is mixed. For instance, Basile's (2001) study of Italian manufacturers finds that both product and process innovators are more likely to export. Similarly, Becker and Egger (2013) find that both associate with higher export propensities in their study of German firms. Crucially, however, these authors note the greater importance of product innovation relative to process innovation, with process innovations increasing export probabilities only in combination with product innovation. The primacy of product innovation is also noted by Cassiman and Golovko $(2007 ; 2011)$ and by Caldera (2010) in their studies of 
Spanish Manufacturers and SMEs. In short, the evidence suggests that "...what actually matters for exporting is product innovation...because the ability to compete in international markets is ultimately influenced by the firm's capacity to successfully market new and improved products" (Ganotakis and Love 2011, p. 280).

Yet, while the empirical literature is consistent in identifying a link between innovation, and especially product innovation, and export performance, it frequently makes an important distinction between entry into exporting and export intensities (e.g. Roper and Love 2002). To this end, the most common finding is that innovation plays a significant role in explaining firms' decisions to become exporters but, conditional on entering export markets, further innovation does not increase export intensity (e.g. Harris and Li 2009; Ganotakis and Love 2011). In short, innovators are more likely to export, but not likely to export more. Yet, to the extent that innovation has been shown to be important for international value creation and survival in export markets (Chang and Rhee 2011; Sui and Baum 2014), it may serve to shift SMEs from intermittent to more continuous modes of exporting and provide an advantage beyond export entry (Bernini et al. 2016).

\subsection{Inducing exporting through innovation policy}

The implications of this relationship for policy design and evaluation are considerable. Policies to support innovation and exporting are staples in most countries. Yet they are rarely coordinated or linked. Public support for exporting is typically aimed at reducing information asymmetries or market entry costs (Golovko and Valentini 2011; Love and Roper 2015). Here the government acts as an 'honest broker', introducing firms to international networks through such activities as trade missions or, less frequently, providing direct support in the form of export grants. Insofar as innovation features as a rationale of such 
policies it is indirectly through the notion that exposing firms to export markets may lead to improved productivity through 'learning by exporting' (Cassiman and Golovko 2011).

On the other side, innovation policies are premised on the basis of market imperfections flowing from the uncertainty, inappropriability and indivisibility of knowledge, which combine to result in a sub-optimal level of investment in innovation from a societal perspective (Chaminade and Edquist 2010). Accordingly, innovation policies are primarily focused on fostering innovation (Borrás and Edquist 2013). Inevitably, where such policies are evaluated, innovation additionality (the extent to which the policy induces more innovation or, the converse, crowds out private sector innovation) is what is measured. And, in these terms, the evidence of positive additionality from grant funding or tax credit type policies is extensive (Love and Roper 2015; Martin 2016).

However, as Borrás and Edquist (2013, p. 1515) observe “...innovation is rarely a goal in itself, but a means to achieve broader potential goals". Innovation is an intermediate output and matters largely to the extent that it enhances competitiveness (Cannone and Ughetto 2014). Exporting is likely to be a better indicator of competitiveness. In this way, one may think of exporting as a particular form of behavioural additionality - i.e. a "scope" additionality (Falk 2007). Scope additionality refers to cases where the coverage of an activity is broadened to encompass a wider range of applications, players or markets than would have been possible without the intervention.

Taken together, the foregoing indicates the potential value in designing and evaluating exporting and innovation policies in joint terms. Indeed, Cassiman and Golovko (2011, p. 70) go as far as to suggest that "policies aimed at innovation promotion...might be an alternative to direct export promotions". The attractiveness of evaluating innovation policies, at least in part, as a function of export additionality is 
heightened in light of evidence that, in SMEs, "exporting is often a rather opportunistic and sporadic activity, rather than a continuous process" (Bernini et al, 2016, p. 1059). This contrasts with evidence on the persistence of innovation activity at the firm level (Triguero and Córcoles 2013; Peters 2009). If innovation policies can be shown to induce more intensive and persistent engagement in export markets, the treatment effect may be substantial. It is this notion, that innovation policies may induce changing export behaviour and may be evaluated on that basis, which provides the inspiration for the current analyses.

However, just as technological innovation can be concerned with either products or processes, or can be more or less novel (O'Brien 2016), so too do the instruments of innovation policy vary. And these variations are likely to have implications for the types of innovation that result and the consequent exporting outcomes. An important source of variation is the administrative level at which the instrument is devised and deployed (Magro and Wilson 2013). Public support is often initiated to better respond to the unique characteristics of the respective territorial ecosystems for innovation activities, with clear implications for policy outcomes. For instance, in their study of high- and low-tech Spanish manufacturers Albors-Garrigos and Barrera (2011) hypothesise that subsidies from European, national and regional origins will have different impacts on firms' innovation performance. They find that European subsidies have no impact on innovation performance - speculating that this results from their influence on precommercial research. In contrast, both regional and national policies had positive impacts upon innovation performance; with regional policies relatively more important in low-tech industries and national policies more important in high-tech industries.

In view of this diversity, this study, rather than studying public support in general terms, provides a comparison of the effects of public innovation funding programmes from sources at three administrative 
levels - regional, national and European. Moreover, innovation support schemes frequently vary by purpose (Laranja et al. 2008; Flanagan et al. 2011). For example, to promote technology leadership, some support programmes may focus on 'technological frontier' innovations, whereas others may nurture SMEs' imitation or technology upgrading. Crucially, to the extent that different policy instruments encourage investments in different types of innovation, they are likely to be more and less successful at inducing new export behaviours.

In light of the foregoing, our interest is in answering the broad question: Does public support for innovation lead to enhanced export performance? Or, more specifically, does public sector induced innovation associate with changing export behaviour in SMEs? In doing so, we are able to disaggregate these rather broad questions and explore the influence of induced innovation stemming from different types of policy intervention on new export entry, on changing exporting intensity and on the persistence of export activity. Our results largely paint a positive picture of the impact of innovation policy on export behaviour, with some important limitations.

\section{Public Innovation Funding for SMEs in Germany}

In detail, our interest is in the public funding for innovation available to German SMEs. Practically, these may be usefully categorised into three administrative levels: regional (State Governments), national (Federal Government) and European (EU Commission and multilateral programmes). At all three levels, support schemes offer grants for innovation projects based on an evaluation of project proposals. Funding programmes mainly differ by the size of funding, by certain project requirements and by their aims and objectives in generating marketable innovations (see Table 1). 
Table 1: Public funding schemes for innovation in SMEs in Germany

\begin{tabular}{|c|c|c|c|c|}
\hline & \multirow{2}{*}{$\begin{array}{l}\text { State } \\
\text { level }^{1)}\end{array}$} & \multicolumn{2}{|c|}{ National level } & \multirow{2}{*}{$\begin{array}{c}\text { European level - } \\
\text { FP7 }^{2)}\end{array}$} \\
\hline & & $\begin{array}{l}\text { Bottom-up } \\
\text { (ZIM) }\end{array}$ & $\begin{array}{l}\text { Technology } \\
\text { programmes }\end{array}$ & \\
\hline Type of R\&D & applied & applied & $\begin{array}{r}\text { technological } \\
\text { frontier }\end{array}$ & $\begin{array}{r}\text { technological } \\
\text { frontier }\end{array}$ \\
\hline Technology focus & $\begin{array}{l}\text { none or } \\
\text { regional } \\
\text { clusters }\end{array}$ & none & 30 fields & 11 fields \\
\hline Typical project size (incl. all partners) & $0.5 \mathrm{~m} €$ & $0.5 \mathrm{~m} €$ & $4 \mathrm{~m} €$ & $8 \mathrm{~m} €$ \\
\hline Typical project duration & $1-2$ years & 2 years & $2-3$ years & 3 years \\
\hline Share of collaborative projects & $\sim 75 \%$ & $\sim 75 \%$ & $>90 \%$ & $100 \%$ \\
\hline Success rate & $50-90 \%$ & $60-70 \%$ & $15-20 \%$ & $10-15 \%$ \\
\hline No. of SMEs receiving a grant (p.a.) & $\sim 2.000$ & $\sim 3.500$ & $\sim 2.500$ & $\sim 350$ \\
\hline Public funding to SMEs in Germany (p.a.) & $\sim 200 \mathrm{~m} €$ & 300 m€ & $\sim 450 \mathrm{m€}$ & $\sim 100 \mathrm{~m} €$ \\
\hline Public funding per SME and per year & $\sim 70 \mathrm{t} €$ & $\sim 50 \mathrm{t} €$ & $\sim 120 \mathrm{t} €$ & $\sim 70 \mathrm{t} €$ \\
\hline
\end{tabular}

Figures refer to the average of the years 2008-2012 or a period close to that one if no programme data for this specific period were available.

1) State programmes differ considerably. The table provides details for the most important group of programmes that provide grant funding for R\&D projects in SMEs.

2) All details only refer to FP7 projects involving SMEs.

Source: Rammer et al. (2016, pp. 137ff).

Among the three levels, the regional funding programmes (supported by State Governments) tend to be smaller in terms of funding amount and innovation project size. More importantly, the schemes often favour local collaborated projects that create market comparative advantages for the region (i.e., the State). Since the State Governments provide the bulk of institutional funding for universities and for many governmental research labs, a particular priority of regional innovation programmes is to establish and intensify collaboration between firms and the regional public research infrastructure.

At the national level there are broadly two types of innovation support measures for SMEs. The single largest programme-in terms of the number of SMEs receiving funding-is the Central Innovation Programme for SMEs (ZIM) run by the Federal Ministry of Economics. Under this scheme, SMEs are allowed to define the project content but must demonstrate significant market performance (e.g., 
increasing innovative sales, improving competitiveness) through a robust commercialisation plan. We term this type of federal funding 'bottom-up', to highlight that the marketable innovative ideas are driven by SMEs. The second group of national programmes focuses on technological novelty. We style these as technology programmes. These programmes support projects that are typically larger in size and often involve SMEs, large enterprises, universities and public research organisations. The technology focus of R\&D projects is largely predetermined by thematic calls.

The funding of innovation projects of German SMEs by European organisations is largely confined to European Commission programmes. In the period covered by our empirical analysis, the single most important EU Commission scheme for SME innovations was the Framework Programme for Research and Technological Development (FP). The programme is similar to the technology-frontier programmes of the German Federal Government. Evaluation and selection criteria for grant recipients are based on scientific excellence and relevant socioeconomic aspects. FP projects are significantly larger in size than projects funded by regional or national programmes, though the amount of funding per SME can be smaller due to the large number of project participants ${ }^{2}$.

In broad terms, the regional and bottom-up Federal support schemes are concerned with supporting applied research. SMEs may use these grants to strengthen their existing comparative advantages and upgrade their product portfolio. Both can be particularly helpful when adapting existing products as well as service innovations for the needs of foreign markets. Federal technology programmes, on the other hand, are more likely to support breakthrough technologies. Projects are generally larger and more ambitious than those supported by the other domestic programmes. While applications to support programmes at the European level may have lower success rates and be marked by greater complexity,

\footnotetext{
2 The other support scheme for SMEs at the European level is the Eurostars programme (Makarow et al. 2014).
} 
access to international collaborators may be particularly important in spurring exporting. In contrast, both the German regional and national programmes incline towards collaboration and knowledge exchange within the domestic innovation system.

None of the four types of programmes explicitly link funding for innovation with a firm's export performance, neither in terms of selection criteria nor as a target output of funding. There are, however, implicit links. Regional and national programmes focus on domestic collaboration and hence favour firms with strong domestic links. By reinforcing these links through the funded projects, firms may be distracted from foreign markets. EU programmes in contrast help firms to engage in international collaboration which may help in accessing foreign markets.

When analysing the impact of innovation funding on exports, it is important to control for likely export subsidies. In the case of Germany, however, there are no trade-related direct subsidies for SMEs. The only government scheme supporting export activities is an export credit guarantee programme (Hermes). Hermes support is limited to exports for which the government identifies a specific public interest and if exporters are subject to a political risk. In 2016, just $1.7 \%$ of total German exports were guaranteed by this programme. The vast majority of guarantees concern exports to developing countries (2016: 83\%). Firms only receive financial support in case an export deal fails. In 2016, total compensation was $€ 0.55$ bn, which is just $0.05 \%$ of total German exports. Compensation is usually confined to a few export deals by larger firms. At the same time, firms paid $€ 0.85 \mathrm{bn}$ for fees, so there is no net subsidy to the firm sector, and the scheme is similar to insurance. In addition, there are four small government schemes that support SMEs in participating in international fairs (one programme focuses on energy technology, another one on young innovative firms, and two are open to all SMEs). All four programmes do not offer subsidies to SMEs but provide information and other non-financial measures. 


\section{Research Method}

\subsection{Empirical Strategy}

The empirical strategy of this study is based on several assumptions. First, following our earlier discussions, we assume that a likely effect of funding on exporting is indirect and is driven from a SME's innovation output. Public funding leads to innovation additionality that, in turn, leads to new entry into exporting or to improved export performance on the part of existing exporters.

Second, we expect that the impact of public funding on exports is heterogeneous. The first source of heterogeneity relates to different levels of innovation additionality (i.e., one programme is more effective in increasing a SME's innovation output than another), whereas the second refers to a qualitative aspect. How innovation contributes to exporting may vary by technology ambition and innovation intent.

Third, this study takes a potential selection bias (Hussinger 2008) into account. Since producing successful innovations (and subsequent improved performance) is often the main policy concern, funding bodies tend to select those firms that promise high innovation success and possess strong capabilities to transfer innovation into economic performance. As a result, funded firms may produce higher innovation output than non-funded firms, though this may simply reflect the firms' higher capabilities rather than a treatment effect. Matching approaches are a widely used method to control for this selection bias (see Czarnitzki and Lopes Bento 2012; 2013; 2015). We follow this stream of research to estimate the contribution of public funding to innovation output. In a second step, we use this result to estimate the (indirect) impact of public funding on the export performance of SMEs. This approach is similar to that 
taken by Czarnitzki and Hussinger (2004) to analyse the impact of public funding on technological performance.

The main advantage of using a matching approach compared to alternative techniques is that it doesn't require assumptions about the functional form of the outcome equation and the distribution of error terms. In addition, we also avoid the problem of finding valid and economically convincing instruments. The main disadvantage of the matching estimator is that it only controls for observed heterogeneity among funded and not funded firms. In the presence of unobserved variables that determine both the probability of receiving public funding and innovation outcome, the matching results would be biased. We believe that this situation is not the case in our analysis since we have a large set of covariates at hand that represents the major determinants of public funding and innovation output.

The first step of our empirical strategy is to estimate the effect of receiving public funding of type $k\left(F_{k}=\right.$ $1, k$ including regional, national bottom-up, national technology programmes, and European funding) on innovation output of type $m\left(I N N_{m}, m\right.$ including sales with new-to-market product innovations, sales with only new-to-firm product innovations, and cost reduction owing to process innovations). This average 'treatment effect on the treated' ${ }^{\pi} \alpha$ is given by the difference between the observed innovation output of type $m$ in year $t$ of a firm $i$ having received public funding of type $k\left({ }^{T} I N N_{k m}\right)$ and the counterfactual situation if the same firm had not received public funding $\left({ }^{C} I N N_{k m}\right)$.

${ }^{T} \alpha_{k m}=E\left({ }^{T} \alpha_{i k m t}\right)=E\left({ }^{T} I N N_{i k m t} / F_{i k t}=1\right)-E\left({ }^{C} I N N_{i k m t} / F_{i k t}=1\right)$

We estimate the counterfactual situation through the familiar propensity score matching method, employing a control group of non-funded firms with very similar characteristics (see Almus and Czarnitzki, 
2003 , for a detailed discussion of employing matching methods for evaluating public innovation funding). ${ }^{3}$ The model used to estimate the propensity score includes variables that affect a firm's decision to seek funding, and the decision of funding agencies to provide financial support to the SME (financial situation, technological competences and other firm resources). It also contains a firm's export activities in order to account for the likelihood of agencies focusing funding on firms that are already active in export markets. Further control variables (vector CTR) include age, size, sector and region. ${ }^{4}$

Our main analyses consider whether the estimated firm- and time-specific treatment effect ${ }^{\top} \alpha$ ikmt affects the export behaviour of firm $i(E X P)$ while also considering the impact of innovation output firm $i$ would have achieved in the absence of public funding $\left({ }^{C} I N N_{m}\right)$. The latter variable is calculated by subtracting the estimated treatment effects ${ }^{T} \alpha$ km from the observed level of innovation output for each of the three output indicators $I N N_{m}$.

${ }^{C} I N N_{i m t}=I N N_{i m t}-\sum_{k}^{T} \alpha_{i k m t}$

\footnotetext{
${ }^{3}$ The matching is performed for each type of public funding and for each observation year separately. For each type of public funding, the control group includes firms that received other types of funding. The treatment effect for a specific programme hence also captures the programme's impact on innovation output compared to funding through other programmes.

${ }^{4}$ Given space constraints, the detailed results for all years and types of funding are not reported here. However, they are available from the authors on request. The results of the propensity score models and the matching analysis for the entire observation period (2001-2014) are shown in Table A2 and Table A4 in the Appendix. Table A3 provides statistics on the accuracy of the matching results. For presentation purposes, for each type of funding, average results over the 14 individual years are shown. The results reveal that the matching quality is satisfactory. For almost all explanatory variables of the propensity score models, differences between treated and not treated firms are insignificant after matching while they have been highly significant for most variables before the matching. There are, however, a few funded firms for which no suitable matching was possible. These firms have been excluded from the next step of our analysis.
} 
Note that ${ }^{C} I N N_{m}$ can be negative if the sum of the estimated treatment effects is larger than the observed innovation output. Treatment effects may be negative if control firms show a higher innovation output than the treated firms. For not funded firms, ${ }^{C} I N N_{m}$ is equal to $I N N_{m}$ since treatment effects for this group of firms are zero by definition.

Export behaviour is measured variously as export propensity (a simple binary indicated by export sales greater than zero), as export intensity (export sales as a percentage of all sales), as new exporting (first time entry into export markets), changing export intensity following innovation, and export persistence. In estimating our models we explore various lag structures between innovation and exporting. The models control for the initial export performance, which implies that the funding effect relates to a change in export performance rather than to the level. We also include a number of control variables (CTR) in order to capture other determinants of SMEs' export activities.

$E X P_{\mathrm{it}+1}=\quad \phi+\beta E X P_{\mathrm{it}}+\sum_{\mathrm{k}} \sum_{\mathrm{m}}{ }^{\top} \beta_{\mathrm{km}}{ }^{\top} \alpha_{\mathrm{ikmt}}+\sum_{\mathrm{m}}{ }^{c} \beta_{\mathrm{m}}{ }^{C} I N N_{\mathrm{imt}}+\chi \mathrm{CTR}_{\mathrm{it}}+\varepsilon_{\mathrm{it}+1}$

The control variables for the export model (5) are inspired by related studies (Arnold and Hussinger 2010; Beise-Zee and Rammer 2006; Cassiman et al. 2010) and include indicators on price and quality advantages (unit labour costs, labour productivity, stock of trade marks, material input share) as well as firm-specific resources and capabilities (size, age, capital intensity, proximity to an international border, part of a multinational group). We also control for the presence of product and process innovation since the innovation strategy of innovative SMEs mirrored by these two types of innovation may also affect export results in addition to the other model variables. All models also include industry and time dummies. The export models are estimated by random effects panel regressions. 


\subsection{Data}

Our study uses data from the German Innovation Survey, which is part of the Community Innovation Surveys (CIS) coordinated by the Statistical Office of the European Commission. In contrast to most other national $\mathrm{CIS}$, the German Innovation Survey is an annual survey based on a panel sample (called the Mannheim Innovation Panel - MIP). The MIP goes beyond the standard requirements of the CIS in terms of size and sector coverage, survey frequency and the information collected through the survey. This is particularly important for our study as we rely heavily on these non-CIS information, including the volume of export sales, labour and material costs, capital stock and more detailed information on innovation results. The annularity of the data is another critical data requirement in order to implement our model approach and to investigate time lags between funding, innovation output and export performance.

The panel sample of the MIP was drawn in 1993 (for manufacturing) and 1995 (for services) and has been updated every second year since to compensate for panel mortality (see Peters and Rammer 2013 for more details on the survey). In this paper, we focus on a 15-year period, ranging from 2001 to 2014 . We chose 2001 as the starting year to exclude the time during the introduction of the new Euro currency (which started in 1999 by fixing exchange rates among national currencies of the Euro area). By abolishing fluctuations in currency exchange rates for many of the most important trading partners of Germany, market expansion was significantly eased for SMEs. Starting our panel after this trade-enhancing event helps to reduce the bias in our analysis. The annual gross sample size of the German Innovation Survey (as of 2014) is around 35,000 firms. As the survey is voluntary, and owing to the high response burden 
due to the lengthy questionnaire, response rates are relatively low at $25 \%$ to $35 \% .{ }^{5}$ The panel consists of a net sample of 5,000 to 8,000 firm observations per year based on questionnaire responses.

For our analysis, we restrict the sample to innovative SMEs as we only have information on public innovation funding for firms that conducted some innovation activities during the three-year reference period. Following the SME definition of the European Union, we use a 250-employee threshold to delineate SMEs from larger enterprises. As we have panel data at hand, we have to decide what to do with firms that pass this threshold over time. We consider a firm being an SME as long it had less than the threshold number of employees at least one year during the observation period and at the same time never more than 500 employees in any year during the observation period. In addition, we exclude very small firms with less than 5 employees in at least one year and never more than 10 employees. An innovative SME is one that conducted activities within a three-year period that were intended to generate or introduce product or process innovation, regardless of whether a product innovation has actually been introduced to the market or a process innovation has been implemented in the firm or whether these activities have been stopped or were still ongoing at the end of the three-year period. Table A1 in the Appendix contains descriptive statistics on all model variables.

\subsection{Key Variables}

The key model variables-product and process innovation, and exporting-are taken directly from the survey. Product innovations refers to sales from new or significantly improved products (goods as well as

\footnotetext{
${ }^{5} \mathrm{~A}$ large-scale non-response survey is conducted every year to control for a likely response bias with respect to $R \& D$ activity and the introduction of product and process innovation.
} 
services) that have been introduced in the market in the previous three-year period. Following the empirical literature on product innovation (see Laursen and Salter 2006; Leiponen and Helfat 2010; Mairesse and Mohnen 2002; Klingebiel and Rammer 2014), we distinguish the degree of novelty by separating between new-to-the-market innovations and other product innovation (i.e., the firm has commercialised an innovation previously introduced to the market by another firm). Product innovation sales are adjusted for firm size by using a firm's total sales as the denominator. Process innovation is measured by the average share of unit cost reduction in year $t$ resulting from process innovations that have been introduced in the previous three-year period. Each innovation output variable is separated into five components: the output that can be attributed to regional funding programmes, to national bottomup funding, to funding from national technology programmes, to funding from EU programmes, and to funding from a firm's own resources. The first four components are estimated based on a propensity score matching while the fifth component, the firm's own efforts, is the difference between a firm's total innovation output and the innovation output that can be attributed to public funding. The export share is calculated by dividing export sales (measured in euros and including all sales to customers located outside Germany) by a firm's total sales. New exporters are identified as firms recording export sales in year $t$, but no export sales in year $t-1 .^{6}$

Most of the explanatory model variables are taken directly from the innovation survey. However, in determining the propensity score (Table A2), the stock of patents is taken from the Patstat database of the European Patent Office (EPO), which has been merged with the MIP based on a name search. The stock of patents measures the number of patents that have been applied at the EPO or at the World

\footnotetext{
${ }^{6}$ We experimented with more rigid definitions of new exporters, considering firms with exports after two (three) consecutive years without export sales as new exporters, as well as firms that had exports in year $t$ for the first time in their firm history. There are only very few firms (less than $0.5 \%$ ) in our sample that meet these criteria. As a result, model estimations do not converge for these more rigid measures of new exporters.
} 
Intellectual Property Organisation through the International Patent Cooperation procedure, using the perpetual inventory method and a depreciation rate of 0.15 . In this step we also use a firm's solvency, based on the solvency index of Germany's largest credit rating agency, Creditreform. This information has been provided by Creditreform. For the export model, we use six variables to control for firm heterogeneity that may affect export performance. Relative productivity is measured by the relation of a firm's gross value added per FTE employee to the respective value in the firm's three-digit industry. The material share gives the share of purchased inputs in total output and is a proxy for likely price advantages from sourcing cheap inputs. Capital intensity is the book value of tangible assets per FTE employee. Unit labour costs indicate the relation between labour costs and labour productivity per unit of output. All data needed for calculating these variables are available from the MIP survey. The trademark stock is used to measure export advantages from branding and firm reputation and is calculated in the same way as the patent stock, using trademark application data from the Office for the Harmonisation in the Internal Market (OHIM, now the European Union Intellectual Property Office). In addition, we include dummy variables if an SME is part of an international enterprise group. We also add dummies if an SME is located in a district bordering another country, or if an SME's district has no direct international border but borders to a bordering region. In both cases we expect trade-enhancing effects from the geographical proximity to customers abroad. For both the public funding and the export model, sector dummies are defined at the 2-digit level using Nace rev. 2. Since sector information for Nace rev. 2 is only available from 2006 onwards, sector dummies for earlier years have been generated using a correspondence table that links Nace rev. 2 with the predecessor classification (Nace rev. 1.1).

\section{Results}


Our analyses begin with estimations on whether 'additional' innovation (i.e. innovation induced by the policy intervention) increases a firm's probability of exporting (export propensity) and increases the share of export sales in total sales (export intensity). In our analyses, we consider different lag structures between innovation and export activity. Table 2 records the results. In line with our earlier discussions, Table 2 distinguishes between new to the market and new to the firm product innovations (which we will hereafter refer to as novel and incremental respectively), and cost reductions resulting from process innovations. Innovation variables are separated by the source of policy intervention ("reg" for regional programmes; "nat-BU" for national bottom-up funding; "nat-tech" for national technology-programmes; and, "EU" for funding by EU programmes). An additional variable incorporates the innovation performance of firms that is based on the firm's own efforts ("own"). For firms with no public funding, all innovation variables related to policy intervention are zero, and "own" represents the firm's entire innovation efforts.

Table 2: Induced innovation and exporting propensity and intensity

\begin{tabular}{|c|c|c|c|c|c|c|}
\hline \multirow[t]{2}{*}{ Variable } & \multicolumn{3}{|c|}{ Export propensity (Exyes) ${ }^{1}$} & \multicolumn{3}{|c|}{ Export intensity of exporters (Exshare) ${ }^{2}$} \\
\hline & $\mathrm{t}$ & $t_{+1}$ & $t+2$ & $\mathrm{t}$ & $t_{+1}$ & $t_{+2}$ \\
\hline Novel (reg) & $0.884(0.259)^{a}$ & $0.560(0.258)^{b}$ & $0.131(0.303)$ & $0.007(0.013)$ & $0.053(0.016)^{a}$ & $0.001(0.015)$ \\
\hline Novel (nat-BU) & $0.261(0.258)$ & $0.169(0.250)$ & $0.158(0.280)$ & $0.018(0.012)$ & $-0.030(0.014)^{b}$ & $0.047(0.014)^{a}$ \\
\hline Novel (nat-tech) & $0.193(0.260)$ & $0.178(0.247)$ & $0.207(0.295)$ & $-0.002(0.012)$ & $0.056(0.013)^{a}$ & $-0.012(0.013)$ \\
\hline Novel (EU) & $0.685(0.341)^{b}$ & $0.440(0.348)$ & $0.742(0.397)^{c}$ & $0.016(0.016)$ & $0.071(0.018)^{a}$ & $0.010(0.018)$ \\
\hline Novel (own) & $0.609(0.161)^{a}$ & $0.419(0.159)^{a}$ & $0.377(0.181)^{b}$ & $0.014(0.008)$ & $0.037(0.010)^{a}$ & $0.008(0.009)$ \\
\hline Increm. (reg) & $0.155(0.197)$ & $0.003(0.196)$ & $0.127(0.225)$ & $-0.002(0.010)$ & $0.014(0.012)$ & $0.003(0.011)$ \\
\hline Increm. (nat-BU) & $0.103(0.176)$ & $0.187(0.186)$ & $0.033(0.213)$ & $0.006(0.009)$ & $-0.006(0.011)$ & $-0.012(0.011)$ \\
\hline Increm. (nat-tech) & $0.003(0.190)$ & $0.543(0.190)^{\mathrm{a}}$ & $-0.182(0.224)$ & $-0.014(0.009)$ & $0.007(0.011)$ & $-0.017(0.011)$ \\
\hline Increm. (EU) & $0.405(0.266)$ & $0.349(0.260)$ & $0.118(0.307)$ & $0.014(0.013)$ & $-0.016(0.015)$ & $0.006(0.015)$ \\
\hline Increm. (own) & $0.142(0.095)$ & $0.210(0.098)^{b}$ & $0.202(0.116)^{c}$ & $0.003(0.005)$ & $0.005(0.006)$ & $-0.010(0.006)$ \\
\hline Cost-red (reg) & $1.363(0.539)^{b}$ & $0.858(0.592)$ & $0.260(0.683)$ & $0.051(0.029)^{c}$ & $-0.035(0.034)$ & $0.041(0.034)$ \\
\hline Cost- & $-0.477(0.555)$ & & & $0.013(0.027)$ & $-0.005(0.0$ & -0.0 \\
\hline Cost-red (nat-tech) & $0.267(0.635)$ & $-1.022(0.558)^{c}$ & $1.202(0.686)^{c}$ & $0.002(0.027)$ & $0.007(0.030)$ & $0.009(0.031)$ \\
\hline Cost-red (EU) & $0.696(0.731)$ & $0.843(0.852)$ & $-0.205(0.962)$ & $0.015(0.037)$ & $-0.070(0.043)$ & $0.056(0.044)$ \\
\hline Cost-red (own) & $0.566(0.301)^{*}$ & $0.260(0.318)$ & $-0.174(0.362)$ & $0.031(0.018)^{c}$ & $-0.033(0.021)$ & $0.014(0.021)$ \\
\hline $\ln ($ age) & $-0.019(0.021)$ & $-0.031(0.020)$ & $-0.025(0.024)$ & $-0.003(0.001)^{b}$ & $-0.004(0.002)^{b}$ & $-0.005(0.001)^{a}$ \\
\hline In(size) & $0.104(0.018)^{a}$ & $0.110(0.019)^{a}$ & $0.093(0.022)^{a}$ & $0.004(0.001)^{a}$ & $0.005(0.002)^{a}$ & $0.004(0.001)^{a}$ \\
\hline Relprod & $0.023(0.012)^{b}$ & $0.049(0.016)^{\mathrm{a}}$ & $0.027(0.020)$ & $0.001(0.001)$ & $0.002(0.002)$ & $0.002(0.001)$ \\
\hline Matshare & $0.086(0.099)$ & $0.127(0.102)$ & $-0.040(0.122)$ & $0.017(0.007)^{b}$ & $-0.002(0.008)$ & $-0.002(0.008)$ \\
\hline ultgroup & $-0.059(0.047)$ & $-0.053(0.048)$ & $0.022(0.056)$ & $0.005(0.003)^{c}$ & $0.008(0.003)^{b}$ & $0.002(0.003)$ \\
\hline In(trademarks) & $0.027(0.005)^{a}$ & $0.034(0.005)^{\mathrm{a}}$ & $0.036(0.006)^{a}$ & $0.000(0.000)$ & $0.001(0.000)^{a}$ & $0.001(0.000)^{c}$ \\
\hline Capint & $-0.224(0.123)^{c}$ & $-0.266(0.120)^{b}$ & $-0.319(0.138)^{b}$ & $0.014(0.011)$ & $0.005(0.013)$ & $0.012(0.013)$ \\
\hline ULC & $-0.135(0.077)^{c}$ & $-0.159(0.081)^{b}$ & $-0.112(0.092)$ & $-0.011(0.005)^{b}$ & $-0.012(0.006)^{b}$ & $-0.000(0.005)$ \\
\hline ULC missing & $-0.175(0.064)^{a}$ & $-0.114(0.065)^{c}$ & $-0.119(0.077)$ & $-0.005(0.004)$ & $-0.009(0.005)^{c}$ & $-0.006(0.005)$ \\
\hline
\end{tabular}




\begin{tabular}{|c|c|c|c|c|c|c|}
\hline Capint missing & $-0.091(0.056)$ & $-0.102(0.059)^{c}$ & $-0.021(0.077)$ & $0.002(0.004)$ & $0.003(0.005)$ & $0.006(0.005)$ \\
\hline Border region & $0.136(0.060)^{b}$ & $0.072(0.061)$ & $0.052(0.072)$ & $0.004(0.004)$ & $0.014(0.005)^{\mathrm{a}}$ & $-0.002(0.004)$ \\
\hline Adjacent to $\mathrm{BR}$ & $0.065(0.056)$ & $0.050(0.057)$ & $-0.003(0.067)$ & $0.006(0.004)$ & $0.009(0.005)^{c}$ & $0.002(0.004)$ \\
\hline Prior exporting & $3.152(0.036)^{a}$ & $2.804(0.038)^{a}$ & $2.970(0.044)^{a}$ & $0.872(0.005)^{a}$ & $0.795(0.006)^{a}$ & $0.869(0.006)^{a}$ \\
\hline $\mathrm{R}^{2}$ adjusted & & & & 0.840 & 0.814 & 0.849 \\
\hline $\operatorname{LR} \chi^{2}$ & $9,448.4$ & $7,543.6$ & $6,036.3$ & 43,262 & 22,329 & 31,636 \\
\hline $\mathrm{N}$ & 19,542 & 15,843 & 12,747 & 12,253 & 9,971 & 8,117 \\
\hline
\end{tabular}

${ }^{1}$ Random-effects probit. ${ }^{2}$ Random-effects GLS. Coefficients with standard errors in parenthesis. Models include year, region and sector dummies, available on request. Significance at the $0.01,0.05$ and 0.1 levels are indicated by superscript $a, b$ and c, respectively.

The results are largely as anticipated. Looking at the export performance of firms not receiving public financial support for innovation, firms with a higher sales share of 'own' innovations are more likely to be exporters - and the effect is present both contemporaneously and with one and two year lags on the dependent variable. There is also some evidence that the share of sales from incremental product 'own' innovation is associated with higher export propensity after some short lag. In short, for firms successfully innovating without public innovation funding, this is the standard finding that product innovators are more likely to be exporters. There is no equivalent finding for process innovation. The results for our 'additional' innovations are mixed. A higher share of sales from novel innovations following public sector financial support at either the regional or EU level associates with a greater likelihood of exporting. Higher innovation sales resulting from support from either national bottom-up or technology schemes does not associate with a higher propensity to export. There is also some evidence that national technology policies leading to a higher share of sales from incremental innovation associate with export propensity after a short lag. Intriguingly, there is also evidence that the introduction of cost reducing process innovations that resulted from regional policies contemporaneously associates with a higher export propensity.

The evidence on a relationship between innovation and export intensity is more consistent. For 'own' innovations, only the share of sales from novel products associate with higher export intensity, after a short lag. Firms with a higher share of novel innovations appear to both export more and be more likely to export. For additional innovations triggered by public funding, again it is only novel product innovation 
that significantly associates with higher export intensity; for all sources of funding intervention. Intriguingly, the lag to positive association is slower in the case of national bottom-up support. Indeed, in this case there is an earlier negative effect on export intensity before the subsequent positive effect.

The simple conclusion to be drawn from this is that public support which induces additional innovation also associates with exporting outcomes. However, the analyses presented in table 2 are limited in one important way. While they identify the relationship between innovation, and induced-innovation, and export behaviour, they don't explore changing behaviour. Our models do control for prior export propensity and intensity, as appropriate. In this way, the evidence points to the reinforcing effects of policy interventions. Nonetheless, consistent with German manufacturing at large, a substantial majority of firms in our sample were exporters prior to the intervention. The export additionality of innovation policy is likely to rest in new export behaviours (e.g. new entry, more intensive exporting or a shift from sporadic to persistent exporting) not simply in maintenance of existing behaviours. To that end, table 3 reports the results of estimations on new exporting, export persistence and changing export intensities. 
Table 3: Induced innovation, new and growing exports and export persistence

\begin{tabular}{|c|c|c|c|c|c|c|c|c|}
\hline & \multicolumn{3}{|c|}{ Entering exporting (Exin) $)^{1}$} & \multicolumn{2}{|c|}{ Persistent exporting (Exper) ${ }^{1}$} & \multicolumn{3}{|c|}{ 3-year-average change in export share (Ch3_ex) $)^{2}$} \\
\hline & $\mathrm{t}$ & $t_{+1}$ & $t_{+2}$ & $\mathrm{t}$ & $t_{+1}$ & $\mathrm{t}$ & $t_{+1}$ & $t_{+2}$ \\
\hline Novel (reg) & $0.566(0.296)^{c}$ & $-0.238(0.318)$ & $-0.604(0.443)$ & $0.298(0.449)$ & $-0.160(0.544)$ & $-0.002(0.008)$ & $0.014(0.007)^{b}$ & $0.005(0.007)$ \\
\hline Novel (nat-BU) & $0.042(0.280)$ & $0.391(0.305)$ & $0.041(0.408)$ & $0.060(0.427)$ & $0.107(0.484)$ & $0.009(0.007)$ & $-0.009(0.006)$ & $0.002(0.002)$ \\
\hline Novel (nat-tech) & $-0.104(0.282)$ & $0.088(0.288)$ & $0.001(0.406)$ & $0.545(0.390)$ & $0.845(0.451)^{c}$ & $-0.001(0.007)$ & $0.015(0.006)^{b}$ & $0.014(0.006)^{b}$ \\
\hline Novel (EU) & $0.416(0.350)$ & $0.102(0.384)$ & $-0.254(0.569)$ & $-0.747(0.543)$ & $-0.063(0.685)$ & $0.007(0.009)$ & $0.026(0.008)^{a}$ & $0.013(0.009)$ \\
\hline Novel (own) & $0.058(0.187)$ & $0.018(0.192)$ & $-0.099(0.255)$ & $0.734(0.277)^{\mathrm{a}}$ & $0.394(0.307)$ & $0.002(0.005)$ & $0.009(0.004)^{b}$ & $0.010(0.004)^{b}$ \\
\hline Increm. (reg) & $-0.138(0.245)$ & $-0.272(0.246)$ & $0.194(0.316)$ & $0.827(0.303)^{\mathrm{a}}$ & $0.745(0.339)^{\mathrm{b}}$ & $0.001(0.006)$ & $0.002(0.005)$ & $0.001(0.005)$ \\
\hline Increm. (nat-BU) & $-0.194(0.216)$ & $0.069(0.233)$ & $-0.336(0.290)$ & $0.732(0.269)^{\mathrm{a}}$ & $0.370(0.310)$ & $0.000(0.005)$ & $-0.003(0.005)$ & $-0.007(0.005)$ \\
\hline Increm. (nat-tech) & $0.112(0.232)$ & $0.256(0.226)$ & $-0.029(0.306)$ & $-0.168(0.291)$ & $0.465(0.339)$ & $-0.013(0.005)^{b}$ & $-0.008(0.005)^{c}$ & $-0.007(0.005)$ \\
\hline Increm. (EU) & $0.039(0.316)$ & $0.297(0.319)$ & $0.054(0.427)$ & $0.922(0.414)^{b}$ & $0.423(0.472)$ & $0.005(0.007)$ & $0.011(0.007)^{\mathrm{c}}$ & $0.002(0.007)$ \\
\hline Increm. (own) & $-0.156(0.131)$ & $-0.046(0.126)$ & $-0.038(0.165)$ & $0.702(0.162)^{\mathrm{a}}$ & $0.547(0.191)^{\mathrm{a}}$ & $-0.001(0.003)$ & $0.003(0.003)$ & $-0.001(0.003)$ \\
\hline Cost-red (reg) & $0.900(0.642)$ & $0.111(0.727)$ & $-1.019(0.968)$ & $0.801(0.885)$ & $0.407(0.955)$ & $0.018(0.016)$ & $-0.001(0.015)$ & $0.000(0.016)$ \\
\hline Cost-red (nat-BU) & $-1.129(0.633)^{c}$ & $-0.114(0.724)$ & $1.199(0.872)$ & $1.180(0.849)$ & $0.070(0.955)$ & $0.004(0.014)$ & $0.006(0.014)$ & $0.006(0.015)$ \\
\hline Cost-red (nat-tech) & $0.052(0.675)$ & $-0.115(0.702)$ & $1.645(0.808)^{b}$ & $-1.919(0.906)^{b}$ & $-1.492(0.982)$ & $-0.019(0.014)$ & $0.008(0.013)$ & $0.027(0.014)^{c}$ \\
\hline Cost-red (EU) & $0.367(0.815)$ & $0.789(0.916)$ & $-1.585(1.387)$ & $-0.149(1.196)$ & $-1.921(1.249)$ & $-0.018(0.021)$ & $-0.015(0.019)$ & $0.004(0.020)$ \\
\hline Cost-red (own) & $0.455(0.356)$ & $0.352(0.390)$ & $-0.231(0.571)$ & $0.148(0.543)$ & $-0.964(0.596)$ & $-0.005(0.010)$ & $-0.006(0.009)$ & $0.004(0.010)$ \\
\hline $\ln ($ age $)$ & $-0.086(0.027)^{a}$ & $-0.101(0.027)^{\mathrm{a}}$ & $-0.100(0.034)^{a}$ & $-0.010(0.062)$ & $-0.000(0.061)$ & $-0.002(0.001)^{b}$ & $-0.002(0.001)^{b}$ & $-0.002(0.001)^{\mathrm{a}}$ \\
\hline $\ln ($ size $)$ & $-0.057(0.024)^{b}$ & $-0.070(0.026)^{c}$ & $-0.076(0.033)^{b}$ & $0.965(0.059)^{\mathrm{a}}$ & $0.936(0.056)^{a}$ & $0.001(0.001)^{c}$ & $0.001(0.001)$ & $0.000(0.001)$ \\
\hline Relprod & $-0.020(0.032)$ & $-0.003(0.027)$ & $-0.030(0.046)$ & $0.203(0.041)^{\mathrm{a}}$ & $0.311(0.082)^{a}$ & $0.000(0.001)$ & $-0.000(0.001)$ & $-0.000(0.001)$ \\
\hline Matshare & $0.017(0.138)$ & $0.072(0.143)$ & $-0.255(0.188)$ & $1.212(0.241)^{\mathrm{a}}$ & $0.637(0.258)^{b}$ & $0.003(0.004)$ & $-0.008(0.004)^{b}$ & $-0.006(0.004)$ \\
\hline ultgroup & $-0.108(0.065)^{c}$ & $-0.039(0.066)$ & $0.132(0.081)$ & $-0.173(0.102)^{c}$ & $-0.192(0.113)^{\mathrm{c}}$ & $0.001(0.002)$ & $0.002(0.001)$ & $-0.001(0.002)$ \\
\hline In(trademarks) & $-0.012(0.007)^{c}$ & $-0.013(0.007)^{c}$ & $-0.011(0.009)$ & $0.220(0.018)^{a}$ & $0.236(0.017)^{\mathrm{a}}$ & $0.000(0.000)$ & $0.000(0.000)$ & $-0.000(0.000)$ \\
\hline Capint & $-0.671(0.301)^{b}$ & $-0.616(0.247)^{b}$ & $-0.432(0.289)$ & $-1.033(0.349)^{a}$ & $-0.241(0.303)$ & $-0.006(0.007)$ & $-0.003(0.006)$ & $-0.001(0.006)$ \\
\hline ULC & $0.065(0.100)$ & $-0.114(0.117)$ & $0.023(0.138)$ & $-0.607(0.158)^{\mathrm{a}}$ & $-0.098(0.173)$ & $-0.000(0.003)$ & $-0.004(0.002)^{c}$ & $0.000(0.003)$ \\
\hline ULC missing & $0.081(0.084)$ & $0.048(0.091)$ & $-0.012(0.113)$ & $-0.577(0.128)^{a}$ & $-0.255(0.143)^{c}$ & $-0.001(0.002)$ & $-0.005(0.002)^{b}$ & $-0.003(0.002)$ \\
\hline Capint missing & $-0.064(0.076)$ & $0.051(0.080)$ & $0.001(0.110)$ & $-0.391(0.170)^{b}$ & $-0.422(0.177)^{b}$ & $0.002(0.003)$ & $0.001(0.002)$ & $0.002(0.003)$ \\
\hline Border region & $0.123(0.077)$ & $-0.009(0.085)$ & $-0.023(0.104)$ & $0.602(0.191)^{a}$ & $0.304(0.188)$ & $0.001(0.002)$ & $0.004(0.002)^{b}$ & $0.000(0.002)$ \\
\hline Adjacent to BR & $-0.067(0.076)$ & $-0.007(0.079)$ & $-0.109(0.101)$ & $0.041(0.178)$ & $0.113(0.182)$ & $0.000(0.002)$ & $0.001(0.002)$ & $-0.000(0.002)$ \\
\hline & & & & & & 0.019 & 0.023 & 0.022 \\
\hline LR $\chi^{2} /$ Wald $\chi^{2}$ & 223.3 & 217.1 & 134.8 & $2,416.9$ & $5,543.1$ & 138.6 & 179.5 & 160.6 \\
\hline $\mathrm{N}$ & 19,057 & 15,463 & 12,194 & 18,101 & 14,950 & 8,117 & 8,814 & 7,742 \\
\hline
\end{tabular}

and 0.1 levels are indicated by superscript a, b and c, respectively. 
In the first instance, there is limited evidence that innovation policies directed at German SMEs create new exporters. The number of non-exporter prior to the interventions was small, so the scope for conversion is correspondingly small. Regardless, only the share of sales from novel innovations induced by regional policy, savings arising from process innovations induced by national bottom-up policy and, after a lag, process innovations induced by national technology policy show some association. Taken as a whole, the evidence that innovation policy support encourages non-exporters to enter export markets is slight.

Our estimations on export persistence, which measures whether a SME had positive exports in three consecutive years, indicate that there is a positive association with 'own' novel innovation share of sales and persistence measured in in time $t$. However, the more consistent results are observed for incremental innovation. Here there is evidence that the share of sales resulting from innovations, both 'own' and 'additional', associates with persistent exporting; likely reflecting the lower market risk associated with introducing products with which customers have some prior familiarity.

Our final concern is with changing export intensities. If induced-innovation doesn't encourage nonexporters to enter export markets, does it increase the export focus of already exporting firms? To explore this question, we use the three year average change in export share in period $t, t_{+1}$ and $t_{+2}$ as dependent variables. The results suggest no contemporaneous effect, other than negative effect associated with the share of sales from incremental product innovations induced by national technology policy support. This is contrasted with the positive effect in $t_{+1}$ of the share of sales from novel product innovations. For 'own' innovations and for additional innovations induced by policy interventions from regional, national technology or EU programmes, the share of novel product sales in total sales associates with growing 
export revenues as a proportion of total revenues. The exception is novel innovations induced through national bottom-up policy, where there is no association with exporting growth.

\section{Discussion and Conclusion}

This research explores the export additionality of innovation policy. Our concern was with the extent to which innovations induced by policy interventions led to new export behaviours in our sample of German SMEs. The simple conclusion is yes; induced innovation leads to new export behaviours. As anticipated, we find that there is variation in impact by the source of the policy and by type of induced innovation. Among this variety, three broad patterns emerge:

In the first instance, a non-finding: we find limited association between innovation, induced or own, and new export activity. This is in contrast to UK evidence that suggest that innovation drives the decision to export but, conditional on exporting, does not increase export intensity (Harris and Li, 2009; Ganotakis and Love, 2011). With the exception of a lagged association between cost reducing process innovation arising from national technology programmes and export entry, we find no robust evidence that innovations create new exporters. As noted earlier, relatively few sample firms were non-exporters. This may be an artefact of our research setting ${ }^{7}$. Germany is an export oriented economy and the costs of entering [European] export markets are low, even for small firms. If SMEs identify export opportunities, they typically would not need policy support to engage in exporting. Hence the 'conversion capacity' that can be addressed by policy is likely to be very low. SME innovation policy in Germany, regardless of source, did not play a significant role in converting non-exporters into exporters. We believe that this is an

\footnotetext{
${ }^{7}$ Or the earlier findings may be an artefact of the UK's island economy.
} 
important counter-finding to earlier UK based studies and further serves to augment the literature on SME internationalisation.

There is, however, evidence that the outcomes of innovation policy positively influence both export persistence and export growth. In the former case, we find evidence of a significant association between incremental product innovation and export persistence. In the relevant literature, firms' export persistence has been viewed as a result of sunk costs associated with establishing an export position (see e.g. Girma et al. 2008). Along with this perspective, we add a view that export persistence is, at least partly, attributable to the prior familiarity embedded in incremental innovations, serving to lower market risk and enhance persistence. Moreover, where incremental innovations include adaptations of existing products to better meet the requirements of customer abroad, this helps to deepen a firms market presence and contributes to export persistence. Only incremental innovations induced by national technology interventions do not positively associated with export persistence. This is likely to be a function of the focus of such programmes, with incremental innovation an incidental rather than intended outcome.

With regards to export growth, we find clear evidence of a positive relationship between novel product innovation and growing export revenue. Here, the exception is sales from novel-product innovations induced by national bottom-up interventions. Again, this is likely to be a function of the design and targeting of this programme. In this case, the funds available are typically smaller and the technology ambition is lower, innovations are likely to be nearer to market and to build upon established competences. Where induced-innovations stray from this, fewer resources and smaller networks may make the likelihood of success lower. Regardless, the broader pattern of novel innovation driving export growth is consistent with the well-established lead-market theory (Beise 2004). Success in cutting-edge 
innovation triggers a process of global diffusion and increases international revenues. That this process may be induced, or heightened, by policy has substantial implications. For example, one clear implication, if growing export markets is a target, is that innovation support for SMEs should challenge the SMEs technological capabilities instead of merely providing funding for doing 'more of the same, but better'.

Generally, our findings are consistent with micro-empirical evidence supporting 'technology gap' or evolutionary models of export advantage (see Dosi et al. 1994 through Dosi et al. 2015). In broad terms, these models follow Vernon (1966) in suggesting that export advantages rest on technological capabilities rather than (inter-sectoral opportunity) cost concerns. For example, drawing upon extensive data from a large set of Italian manufacturers over the period 1998-2006, Dosi et al. (2015, p. 1809) observe that technology and innovation (proxied by patents and innovations) "play a major role" in firms' export propensities and intensities, but that there is "no widespread evidence that lower costs of labor boost innovation". These authors also note the relatively greater influence of product over process innovation in determining firms' export success. Indeed, similar to our observations on the role of innovation in export persistence, Dosi et al. (2015) observe that the exports of innovating firms are less susceptible to external shocks than those of non-innovating firms.

In summary, research on innovation often loses sight of the notion that innovation is an intermediate output; a means to achieve a broader goal (Cannone and Ughetto 2014; Borrás and Edquist 2013). Policy makers must view innovation policy in the context of achieving broader 'competitiveness' goals. In this study, we provide evidence that, beyond innovation additionality, innovation policy has a subsequent effect on important dimensions of export additionally in SMEs. Taken as a whole, our findings suggest that incremental product innovation helps maintain export market presence, but that it is novel product innovation that drives export growth. That this can be achieved through policy-induced innovation has 
important implications for both SME managers and those concerned with the design and implementation of innovation policies.

For the former, it gives some guidance in defending and attacking export markets. Moreover, given the essentially networked nature or innovation policies, it is important that firms are able to present themselves as capable collaborators. This is likely to be increasingly important as projects move closer to the technological frontier and as novel innovations are the intended outcomes. Past research suggests that capable collaborators are likely to make substantial investment in absorptive capacity (Fritsch and Lukas 2001; Tether 2002); in research and development and in human capital. These are also important determinants of access to public innovation support.

For the latter, our results endorse the use of innovation policy as export policy. However, they reinforce the notion that varying innovation outcomes and export outcomes are often linked. Policies intended to grow export markets are likely to focus on novel product innovation. Whilst policies intended to defend export positions may, more successfully, focus on incremental innovations - on keeping pace with competitors.

Finally, recent evidence suggests that the link between innovation and exporting may be weaker in Supplier Dominated firms (Bogliacino and Pianta, 2016) and during downswings of the business cycle (Guarascio et al, 2015). This is consistent with more general observations on the heterogeneity of the innovation performance relationship (e.g. Coad and Rao, 2008) and suggests important contingencies ${ }^{8}$. Space constraints hinder our ability to explore these contingencies fully. However, understanding whether policy advice may differ during a recession or across broad industrial categories is an important next step.

\footnotetext{
${ }^{8}$ We are grateful to an anonymous reviewer for raising this issue.
} 


\section{References}

Albors-Garrigos, Jose, and Rosa Rodriguez Barrera. 2011. “Impact of Public Funding on a Firm’s Innovation Performance: Analysis of Internal and External Moderating Factors." International Journal of Innovation Management 15(6):1297-1322.

Almus, Matthias, and Dirk Czarnitzki. 2003. "The effects of public R\&D subsidies on firms' innovation activities: the case of Eastern Germany." Journal of Business and Economic Statistics 21(2):226236.

Alvarez, Roberto, and Raymond Robertson. 2004. "Exposure to Foreign Markets and Plant-Level Innovation: Evidence from Chile and Mexico." The Journal of International Trade \& Economic Development 13 (1):57-87.

Arnold, Jens Matthias, and Katrin Hussinger. 2010. "Exports versus FDI in German manufacturing: firm performance and participation in international markets." Review of International Economics 18(4):595-606.

Autio, Erkko, Sami Kanninen, and Robin Gustafsson. 2008. "First-and Second-Order Additionality and Learning Outcomes in Collaborative R\&D Programs." Research Policy 37 (1):59-76.

Aw, Bee Yan, Mark J. Roberts, and Daniel Yi Xu. 2011. "R\&D Investment, Exporting, and Productivity Dynamics." The American Economic Review 101 (4):1312-1344.

Basile, Roberto. 2001. “Export Behaviour of Italian Manufacturing Firms over the Nineties: The Role of Innovation." Research Policy 30(8):1185-1201.

Becker, Sascha O. and Peter H. Egger. 2013. “Endogenous Product versus Process Innovation and a Firm's Propensity to Export." Empirical Economics 44(1):1-26. 
Beise, Marian 2004. "Lead markets: country-specific drivers of the global diffusion of innovations."

Research Policy 33(6-7):997-1018.

Beise-Zee, Rian and Christian Rammer. 2006. "Local user-producer interaction in innovation and export performance of firms." Small Business Economics 27(2-3):207-222.

Bernini, Michele, Jun Du and James H. Love. 2016. “Explaining Intermittent Exporting: Exit and Conditional Re-Entry in Export Markets." Journal of International Business Studies 47(9):10581076.

Bogliacino, Francesco, Matteo Lucchese, Leopoldo Nascia, and Mario Pianta. 2017. "Modeling the Virtuous Circle of Innovation. A Test on Italian Firms." Industrial and Corporate Change 26(3):467-484.

Bogliacino, Francesco, and Mario Pianta. 2016. "The Pavitt Taxonomy, revisited: patterns of innovation in manufacturing and services." Economia Politica 33(2):153-180.

Borrás, Susana, and Charles Edquist. 2013. "The Choice of Innovation Policy Instruments." Technological Forecasting and Social Change 80(8):1513-1522.

Caldera, Aida. 2010. "Innovation and Exporting: Evidence from Spanish Manufacturing Firms." Review of World Economics 146(4):657-689.

Cannone, Giusy, and Elisa Ughetto. 2014. “Funding Innovation at Regional Level: An Analysis of a Public Policy Intervention in the Piedmont Region." Regional Studies 48(2):270-283.

Cassiman, Bruno, and Elena Golovko. 2007. "Innovation and the Export-Productivity Link." https://papers.ssrn.com/soL3/papers.cfm?abstract_id=1138524.

- - . 2011. "Innovation and Internationalization through Exports." Journal of International Business Studies 42(1):56-75.

Cassiman, Bruno, Elena Golovko, and Ester Martínez-Ros. 2010. "Innovation, Exports and Productivity." International Journal of Industrial Organization 28(4):372-376. 
Chaminade, Cristina, and Charles Edquist. 2010. "Rationales for Public Policy Intervention in the Innovation Process: A Systems of Innovation Approach", in R.Smits, S. Kuhlmann and P. Shapira (ed.), The Theory and Practice of Innovation Policy, An International Research Handbook: 95-114 Edward Elgar Publishing.

Chang, Sea-Jin, and Jay Hyuk Rhee. 2011. "Rapid FDI Expansion and Firm Performance." Journal of International Business Studies 42(8):979-994.

Clarysse, Bart, Mike Wright, and Philippe Mustar. 2009. "Behavioural Additionality of R\&D Subsidies: A Learning Perspective." Research Policy 38(10):1517-1533.

Coad, Alex, and Rekha Rao. 2008. "Innovation and firm growth in high-tech sectors: A quantile regression approach." Research Policy 37(4):633-648.

Cohen, Wesley M. 2010. "Fifty Years of Empirical Studies of Innovative Activity and Performance." in H. Bronwyn and N Rosenberg (ed.), Handbook of the Economics of Innovation 1:129-213. North Holland, UK.

Crépon, Bruno, Emmanuel Duguet, and Jacques Mairessec. 1998. “Research, Innovation and Productivity: An Econometric Analysis at the Firm Level." Economics of Innovation and New Technology 7(2):115-158.

Czarnitzki, Dirk, and Cindy Lopes Bento. 2012. "Evaluation of public R\&D policies: a cross-country comparison." World Review of Science, Technology and Sustainable Development 9(2-4):254282.

----- . 2013. "Value for money? New microeconometric evidence on public R\&D grants in Flanders." Research Policy 42(1):76-89.

-----. 2015. "Innovation subsidies: does the funding source matter for innovation intensity and performance? Empirical evidence from Germany." Industry and Innovation 21(5):380-409. 
Czarnitzki, Dirk, and Katrin Hussinger. 2004., The Link between R\&D Subsidies, R\&D Spending and Technological Performance, ZEW Discussion Paper 04-56, Mannheim.

Damijan, Jože P., Črt Kostevc, and Sašo Polanec. 2010. “From Innovation to Exporting or Vice Versa?” The World Economy 33(3):374-398.

Dosi, Giovanni, Marco Grazzi and Daniele Moschella (2015) "Technology and costs in international competitiveness: From countries and sectors to firms", Research Policy, 44: 1795-1814.

Dosi, Giovanni, Silvia Fabiani, Roberta Aversi and Mara Meacci (1994) "The dynamics of international differentiation: A multi-country evolutionary model", Industrial and Corporate Change, 3(1): 225-242.

Falk, Rahel. 2007. "Measuring the Effects of Public Support Schemes on Firms' Innovation Activities: Survey Evidence from Austria." Research Policy 36(5):665-679.

Fassio, Claudio. 2017. "Export-led innovation: The role of export destinations", Industrial and Corporate Change 27 (1): 149-171.

Filatotchev, Igor, and Jenifer Piesse. 2009. “R\&D, Internationalization and Growth of Newly Listed Firms: European Evidence." Journal of International Business Studies 40(8):1260-1276.

Flanagan, Kieron, Elvira Uyarra, and Manuel Laranja. 2011. “Reconceptualising the 'Policy Mix'for Innovation." Research Policy 40(5):702-713.

Fritsch, Michael, and Rolf Lukas. 2001. "Who Cooperates on R\&D?” Research Policy 30(2):297-312.

Ganotakis, Panagiotis, and James H. Love. 2011. “R\&D, Product Innovation, and Exporting: Evidence from UK New Technology Based Firms." Oxford Economic Papers 63(2):279-306.

----- . 2012. "Export propensity, export intensity and firm performance: The role of the entrepreneurial founding team." Journal of International Business Studies 43(8):693-718.

Georghiou, Luke. 1998. "Issues in the Evaluation of Innovation and Technology Policy." Evaluation $4(1): 37-51$. 
Girma, Sourafel, Holger Görg, and Aoife Hanley. 2008. "R\&D and Exporting: A Comparison of British and Irish Firms." Review of World Economics 144(4):750-773.

Golovko, Elena, and Giovanni Valentini. 2011. “Exploring the Complementarity between Innovation and Export for SMEs' Growth." Journal of International Business Studies 42(3):362-380.

Guarascio, Dario, Mario Pianta, Matteo Lucchese, and Francesco Bogliacino. 2015. "Business cycles, technology and exports." Economia Politica 32 (2): 167-200

Hall, Bronwyn H., Francesca Lotti, and Jacques Mairesse. 2009. “Innovation and Productivity in SMEs: Empirical Evidence for Italy." Small Business Economics 33(1):13-33.

Harris, Richard, and Qian Cher Li. 2009. “Exporting, R\&D, and Absorptive Capacity in UK Establishments." Oxford Economic Papers 61(1):74-103.

Hussinger, Katrin. 2008. "R\&D and subsidies at the firm level: An application of parametric and semiparametric two-step selection models." Journal of Applied Econometrics 23:729-747.

Ito, Keiko, and Sébastien Lechevalier. 2010. “Why Some Firms Persistently Out-Perform Others: Investigating the Interactions between Innovation and Exporting Strategies." Industrial and Corporate Change 19(6):1997-2039.

Klingebiel, Ronald, and Christian Rammer. 2014. "Resource allocation strategy for innovation portfolio management." Strategic Management Journal 35(2):246-268.

Kiss, Andreea, Stephanie Fernhaber, and Patricia McDougall-Covon. 2018. " Slack, innovation, and export intensity: Implications for small and medium-sized enterprises." Entrepreneurship Theory and Practice, forthcoming https://doi.org/10.1111/etap.12276.

Laursen, Keld, and Ammon Salter. 2006. "Open for innovation: The role of openness in explaining innovation performance among UK manufacturing firms." Strategic Management Journal 27(2):131-150. 
Laranja, Manuel, Elvira Uyarra, and Kieron Flanagan. 2008. “Policies for Science, Technology and Innovation: Translating Rationales into Regional Policies in a Multi-Level Setting." Research Policy 37(5):823-835.

Leiponen, Aija, and Constance E. Helfat. 2010. "Innovation objectives, knowledge sources, and the benefits of breadth." Strategic Management Journal 31(2):224-236.

Love, James H., and Panagiotis Ganotakis. 2013. “Learning by Exporting: Lessons from High-Technology SMEs." International Business Review 22(1):1-17.

Love, James H., and Stephen Roper. 2015. "SME Innovation, Exporting and Growth: A Review of Existing Evidence." International Small Business Journal 33(1):28-48.

Magro, Edurne, and James R. Wilson. 2013. “Complex Innovation Policy Systems: Towards an Evaluation Mix." Research Policy 42(9):1647-1656.

Mairesse, Jacques, and Pierre Mohnen. 2002. "Accounting for innovation and measuring innovativeness: An illustrative framework and an application." American Economic Review 92(2):226-230.

Makarow, Marja, Georg Licht, I. Caetano, Dirk Czarnitzki, and Sirin Elçi. 2014. "Final Evaluation of Eurostars Joint Programme." Final Report, European Commission. Ref. Ares (2014), 3906990-24.

Martin, Ben R. 2016. "R\&D Policy Instruments-a Critical Review of What We Do and Don't Know." Industry and Innovation 23(2):157-176.

Martins, Pedro S., and Yong Yang. 2009. "The Impact of Exporting on Firm Productivity: A Meta-Analysis of the Learning-by-Exporting Hypothesis." Review of World Economics 145(3):431-445.

McCann, Philip, and Raquel Ortega-Argilés. 2016. “Smart Specialisation, Entrepreneurship and SMEs: Issues and Challenges for a Results-Oriented EU Regional Policy." Small Business Economics 46(4):537-552. 
O’Brien, Kieran. 2016. “Is Newest Always Best? Firm-Level Evidence to Challenge a Focus on HighCapability Technological (Product or Process) Innovation." Economics of Innovation and New Technology 25(8):747-768.

Parisi, Maria Laura, Fabio Schiantarelli, and Alessandro Sembenelli. 2006. "Productivity, Innovation and R\&D: Micro Evidence for Italy." European Economic Review 50(8):2037-2061.

Peters, Bettina. 2009. "Persistence of Innovation: Stylised Facts and Panel Data Evidence." The Journal of Technology Transfer 34(2):226-243.

Peters, Bettina, Christian Rammer. 2013. "Innovation Panel Surveys in Germany." In F. Gault (ed). Handbook on Innovation Indicators and Measurement. Cheltenham: Edward Elgar:135-177.

Rammer, Christian, Sandra Gottschalk, Bettina Peters, Johannes Bersch, and Daniel Erdsiek. 2016. "Die Rolle von KMU für Forschung und Innovation in Deutschland." Studien zum deutschen Innovationssystem 10/2016, Berlin: Commission of Experts for Research and Innovation.

Roper, Stephen, and James H. Love. 2002. "Innovation and Export Performance: Evidence from the UK and German Manufacturing Plants." Research Policy 31(7):1087-1102.

Salomon, Robert, and Byungchae Jin. 2008. “Does Knowledge Spill to Leaders or Laggards? Exploring Industry Heterogeneity in Learning by Exporting." Journal of International Business Studies 39(1):132-150.

Salomon, Robert M., and J. Myles Shaver. 2005. "Learning by Exporting: New Insights from Examining Firm Innovation." Journal of Economics \& Management Strategy 14(2):431-460.

Sui, Sui, and Matthias Baum. 2014. "Internationalization Strategy, Firm Resources and the Survival of SMEs in the Export Market." Journal of International Business Studies 45(7):821-841.

Tether, Bruce S. 2002. "Who Co-Operates for Innovation, and Why: An Empirical Analysis." Research Policy 31(6):947-967. 
Triguero, Angela, and David Córcoles. 2013. "Understanding Innovation: An Analysis of Persistence for Spanish Manufacturing Firms." Research Policy 42(2):340-352.

Vernon, Raymond. 1966. "International Investment and International Trade in the Product Cycle." The Quarterly Journal of Economics, 190-207.

Wakelin, Katharine. 1998. "Innovation and Export Behaviour at the Firm Level." Research Policy 26(7):829-841. 


\section{Appendix}

Table A1: Descriptive statistics of model variables

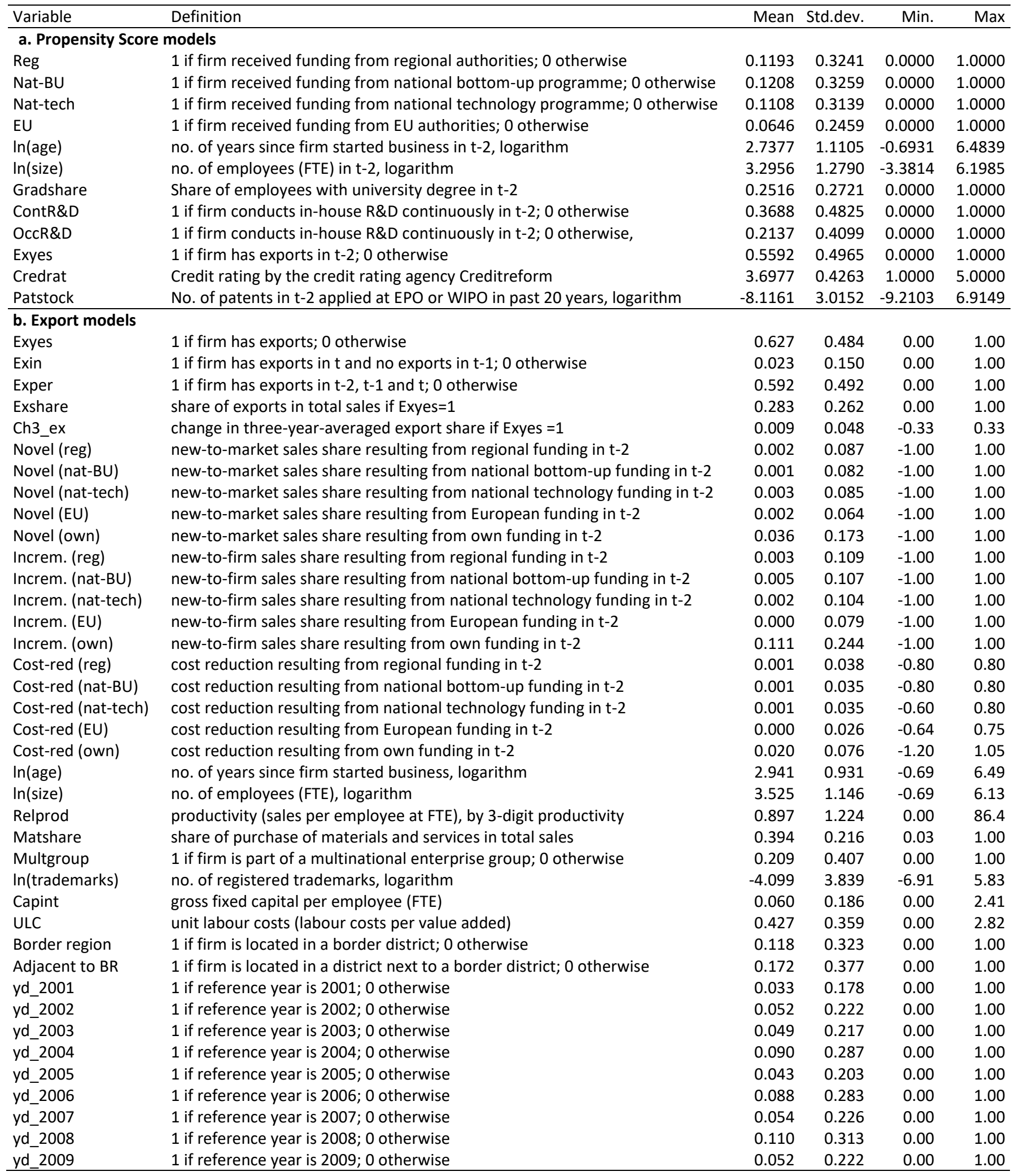




\begin{tabular}{|c|c|c|c|c|c|}
\hline yd_2010 & 1 if reference year is $2010 ; 0$ otherwise & 0.109 & 0.312 & 0.00 & 1.00 \\
\hline yd_2011 & 1 if reference year is $2011 ; 0$ otherwise & 0.056 & 0.230 & 0.00 & 1.00 \\
\hline yd_2013 & 1 if reference year is $2013 ; 0$ otherwise & 0.051 & 0.221 & 0.00 & 1.00 \\
\hline sd_8 & 1 if Nace (rev. 2). 5 to 9 or 35 to $39 ; 0$ otherwise & 0.053 & 0.225 & 0.00 & 1.00 \\
\hline sd_10 & 1 if Nace (rev. 2). 10; 0 otherwise & 0.029 & 0.167 & 0.00 & 1.00 \\
\hline sd_11 & 1 if Nace (rev. 2). 11 to $12 ; 0$ otherwise & 0.008 & 0.092 & 0.00 & 1.00 \\
\hline sd_15 & 1 if Nace (rev. 2). 15; 0 otherwise & 0.006 & 0.076 & 0.00 & 1.00 \\
\hline sd_16 & 1 if Nace (rev. 2). 16; 0 otherwise & 0.015 & 0.121 & 0.00 & 1.00 \\
\hline sd_17 & 1 if Nace (rev. 2). 17; 0 otherwise & 0.017 & 0.128 & 0.00 & 1.00 \\
\hline sd_18 & 1 if Nace (rev. 2). 18; 0 otherwise & 0.016 & 0.125 & 0.00 & 1.00 \\
\hline sd_19 & 1 if Nace (rev. 2). 19; 0 otherwise & 0.002 & 0.048 & 0.00 & 1.00 \\
\hline sd_24 & 1 if Nace (rev. 2). 24; 0 otherwise & 0.017 & 0.129 & 0.00 & 1.00 \\
\hline sd_25 & 1 if Nace (rev. 2). 25 or $33.11 ; 0$ otherwise & 0.065 & 0.247 & 0.00 & 1.00 \\
\hline sd_26 & 1 if Nace (rev. 2). 26 o 33.13; 0 otherwise & 0.079 & 0.269 & 0.00 & 1.00 \\
\hline sd_27 & 1 if Nace (rev. 2). 27 or 33.14; 0 otherwise & 0.039 & 0.193 & 0.00 & 1.00 \\
\hline sd_28 & 1 if Nace (rev. 2). 28, 33.12 or 33.2 ; 0 otherwise & 0.090 & 0.286 & 0.00 & 1.00 \\
\hline sd_29 & 1 if Nace (rev. 2). 29; 0 otherwise & 0.014 & 0.118 & 0.00 & 1.00 \\
\hline sd_30 & 1 if Nace (rev. 2). $30,33.14$ to $33.17 ; 0$ otherwise & 0.011 & 0.104 & 0.00 & 1.00 \\
\hline sd_31 & 1 if Nace (rev. 2). 31; 0 otherwise & 0.015 & 0.120 & 0.00 & 1.00 \\
\hline sd_32 & 1 if Nace (rev. 2). 32 to ; 0 otherwise & 0.026 & 0.159 & 0.00 & 1.00 \\
\hline sd_41 & 1 if Nace (rev. 2). 41 to $43 ; 0$ otherwise & 0.009 & 0.097 & 0.00 & 1.00 \\
\hline sd_46 & 1 if Nace (rev. 2). 45 to $47 ; 0$ otherwise & 0.041 & 0.199 & 0.00 & 1.00 \\
\hline sd_81 & 1 if Nace (rev. 2). 80 to $81 ; 0$ otherwise & 0.012 & 0.110 & 0.00 & 1.00 \\
\hline sd_82 & 1 if Nace (rev. 2). 82; 0 otherwise & 0.008 & 0.090 & 0.00 & 1.00 \\
\hline sd_99 & 1 if Nace (rev. 2). 1-3, 55-56, 68, 75, 77, 84-99; 0 otherwise & 0.004 & 0.065 & 0.00 & 1.00 \\
\hline reg_1 & 1 if firm located in Schleswig-Holstein; 0 otherwise & 0.019 & 0.138 & 0.00 & 1.00 \\
\hline reg_2 & 1 if firm located in Hamburg; 0 otherwise & 0.014 & 0.116 & 0.00 & 1.00 \\
\hline reg_3 & 1 if firm located in Lower Saxony; 0 otherwise & 0.070 & 0.254 & 0.00 & 1.00 \\
\hline reg_4 & 1 if firm located in Bremen; 0 otherwise & 0.015 & 0.123 & 0.00 & 1.00 \\
\hline reg_5 & 1 if firm located in North-Rhine Westfalia; 0 otherwise & 0.150 & 0.357 & 0.00 & 1.00 \\
\hline reg_6 & 1 if firm located in Hesse; 0 otherwise & 0.056 & 0.230 & 0.00 & 1.00 \\
\hline reg_7 & 1 if firm located in Rhineland-Palatine; 0 otherwise & 0.030 & 0.172 & 0.00 & 1.00 \\
\hline reg_8 & 1 if firm located in Baden-Wuerttemberg; 0 otherwise & 0.136 & 0.343 & 0.00 & 1.00 \\
\hline reg_9 & 1 if firm located in Bavaria; 0 otherwise & 0.129 & 0.335 & 0.00 & 1.00 \\
\hline reg_10 & 1 if firm located in Saar; 0 otherwise & 0.008 & 0.092 & 0.00 & 1.00 \\
\hline reg_11 & 1 if firm located in Berlin; 0 otherwise & 0.057 & 0.232 & 0.00 & 1.00 \\
\hline reg_12 & 1 if firm located in Brandenburg; 0 otherwise & 0.043 & 0.203 & 0.00 & 1.00 \\
\hline reg_13 & 1 if firm located in Mecklenburg West-Pomerania; 0 otherwise & 0.025 & 0.157 & 0.00 & 1.00 \\
\hline reg_14 & 1 if firm located in Saxony; 0 otherwise & 0.123 & 0.329 & 0.00 & 1.00 \\
\hline reg_15 & 1 if firm located in Saxony-Anhalt; 0 otherwise & 0.049 & 0.217 & 0.00 & 1.00 \\
\hline reg_16 & 1 if firm located in Thuringia; 0 otherwise & 0.074 & 0.261 & 0.00 & 1.00 \\
\hline
\end{tabular}


Table A2: Results of propensity score models on receiving public funding

\begin{tabular}{|c|c|c|c|c|}
\hline & $\begin{array}{l}\text { Regional funding } \\
\text { (reg) }\end{array}$ & $\begin{array}{l}\text { National bottom-up } \\
\text { funding (nat-BU) }\end{array}$ & $\begin{array}{l}\text { National technology } \\
\text { funding (nat-tech) }\end{array}$ & $\begin{array}{l}\text { European funding } \\
\text { (EU) }\end{array}$ \\
\hline $\ln ($ age $), t-2$ & $-0.069^{a}(0.010)$ & $0.001(0.011)$ & $-0.099^{a}(0.011)$ & $-0.069^{a}(0.012)$ \\
\hline In(size) , t-2 & $0.052^{a}(0.009)$ & $0.011(0.010)$ & $-0.022^{b}(0.010)$ & $0.073^{a}(0.011)$ \\
\hline Gradshare, t-2 & $0.638^{\mathrm{a}}(0.047)$ & $0.656^{\mathrm{a}}(0.048)$ & $1.006^{\mathrm{a}}(0.048)$ & $0.732^{\mathrm{a}}(0.053)$ \\
\hline ContR\&D, t-2 & $0.602^{\mathrm{a}}(0.027)$ & $0.880^{\mathrm{a}}(0.029)$ & $0.916^{\mathrm{a}}(0.032)$ & $0.551^{\mathrm{a}}(0.033)$ \\
\hline OccR\&D, t-2 & $0.307^{a}(0.029)$ & $0.479^{a}(0.032)$ & $0.536^{\mathrm{a}}(0.036)$ & $0.296^{\mathrm{a}}(0.037)$ \\
\hline Exyes, $\mathrm{t}-2$ & $0.085^{a}(0.024)$ & $0.245^{\mathrm{a}}(0.025)$ & $0.254^{\mathrm{a}}(0.026)$ & $0.239^{a}(0.029)$ \\
\hline Credrat, t-2 & $-0.015(0.026)$ & $0.035(0.027)$ & $-0.045(0.028)$ & $-0.012(0.031)$ \\
\hline Patstock, t-2 & $0.019^{a}(0.003)$ & $0.013^{a}(0.003)$ & $0.035^{a}(0.003)$ & $0.023^{a}(0.003)$ \\
\hline $\operatorname{LR} \chi^{2}$ & $5,897.8$ & $6,969.3$ & $7,620.9$ & $3,176.3$ \\
\hline $\mathrm{N}$ & 38,438 & 38,438 & 38,438 & 38,438 \\
\hline
\end{tabular}


Table A3: Statistics on matching results

\begin{tabular}{|c|c|c|c|c|c|c|c|c|c|c|c|c|c|c|c|c|c|}
\hline & & \multicolumn{4}{|c|}{ Regional funding } & \multicolumn{4}{|c|}{ National bottom-up funding } & \multicolumn{4}{|c|}{ National technology funding } & \multicolumn{4}{|c|}{ European funding } \\
\hline & & $\begin{array}{r}\text { on } \\
\text { support } \\
\end{array}$ & $\begin{array}{r}\text { off } \\
\text { support } \\
\end{array}$ & $\begin{array}{r}\text { not } \\
\text { treated } \\
\end{array}$ & Total & $\begin{array}{r}\text { on } \\
\text { support }\end{array}$ & $\begin{array}{r}\text { off } \\
\text { support } \\
\end{array}$ & $\begin{array}{r}\text { not } \\
\text { treated } \\
\end{array}$ & Total & $\begin{array}{r}\text { on } \\
\text { support } \\
\end{array}$ & $\begin{array}{r}\text { off } \\
\text { support } \\
\end{array}$ & $\begin{array}{r}\text { not } \\
\text { treated } \\
\end{array}$ & Total & $\begin{array}{r}\text { on } \\
\text { support } \\
\end{array}$ & $\begin{array}{r}\text { off } \\
\text { support } \\
\end{array}$ & $\begin{array}{r}\text { not } \\
\text { treated } \\
\end{array}$ & Total \\
\hline \multirow{2}{*}{\multicolumn{2}{|c|}{ No. of observations }} & 229 & 7 & 1,700 & 1,936 & 222 & 4 & 1,709 & 1,936 & 209 & 5 & 1,721 & 1,936 & 123 & 1 & 1,812 & 1,936 \\
\hline & & treated & control & $\mathrm{t}$ & & treated & control & $t$ & & treated & control & $\mathrm{t}$ & & treated & control & $t$ & \\
\hline \multirow{2}{*}{$\begin{array}{l}\ln (\text { age }), \\
\mathrm{t}-2\end{array}$} & unmatched & 2.36 & 2.73 & -4.53 & $* * *$ & 2.39 & 2.71 & -3.43 & $* * *$ & 2.32 & 2.72 & -4.86 & $* * *$ & 2.36 & 2.70 & -2.99 & $* * *$ \\
\hline & matched & 2.37 & 2.55 & -2.01 & $* *$ & 2.40 & 2.54 & -1.46 & & 2.34 & 2.55 & -2.38 & $* *$ & 2.36 & 2.55 & -1.40 & \\
\hline \multirow{2}{*}{$\begin{array}{l}\ln (\text { size) } \\
\mathrm{t}-2\end{array}$} & unmatched & 3.35 & 3.27 & 0.92 & & 3.28 & 3.27 & 0.37 & & 3.24 & 3.29 & -0.75 & & 3.42 & 3.27 & 1.20 & \\
\hline & matched & 3.35 & 3.29 & 0.56 & & 3.29 & 3.30 & 0.00 & & 3.25 & 3.26 & -0.38 & & 3.41 & 3.32 & 0.63 & \\
\hline \multirow{2}{*}{$\begin{array}{l}\text { Gradshare, } \\
\mathrm{t}-2\end{array}$} & unmatched & 0.38 & 0.23 & 7.76 & $* * *$ & 0.41 & 0.23 & 9.08 & $* * *$ & 0.45 & 0.22 & 11.96 & $* * *$ & 0.42 & 0.24 & 7.22 & $* * *$ \\
\hline & matched & 0.36 & 0.32 & 1.56 & & 0.40 & 0.35 & 1.58 & & 0.44 & 0.38 & 2.23 & $* *$ & 0.41 & 0.37 & 1.18 & \\
\hline \multirow{2}{*}{$\begin{array}{l}\text { ContR\&D, } \\
t-2\end{array}$} & unmatched & 0.68 & 0.32 & 10.66 & $* * *$ & 0.76 & 0.31 & 13.46 & $* * *$ & 0.79 & 0.31 & 13.97 & $* * *$ & 0.74 & 0.34 & 8.90 & $* * *$ \\
\hline & matched & 0.67 & 0.59 & 1.64 & & 0.76 & 0.64 & 2.39 & $* *$ & 0.79 & 0.71 & 1.84 & $*$ & 0.74 & 0.66 & 1.12 & \\
\hline \multirow{2}{*}{$\begin{array}{l}\text { OccR\&D, } \\
\mathrm{t}-2\end{array}$} & unmatched & 0.17 & 0.22 & -1.50 & & 0.16 & 0.22 & -2.02 & $* *$ & 0.15 & 0.22 & -2.36 & $* *$ & 0.15 & 0.22 & -1.66 & $*$ \\
\hline & matched & 0.18 & 0.17 & 0.41 & & 0.16 & 0.16 & 0.04 & & 0.15 & 0.15 & 0.14 & & 0.15 & 0.15 & 0.13 & \\
\hline \multirow{2}{*}{$\begin{array}{l}\text { Exyes, } \\
\mathrm{t}-2\end{array}$} & unmatched & 0.69 & 0.52 & 4.66 & $* * *$ & 0.74 & 0.52 & 6.28 & $* * *$ & 0.75 & 0.52 & 6.30 & $* * *$ & 0.74 & 0.53 & 4.60 & $* * *$ \\
\hline & matched & 0.69 & 0.66 & 0.54 & & 0.73 & 0.70 & 0.71 & & 0.75 & 0.71 & 0.75 & & 0.74 & 0.68 & 0.89 & \\
\hline \multirow{2}{*}{$\begin{array}{l}\text { Credrat, } \\
t-2\end{array}$} & unmatched & 3.57 & 3.61 & -0.80 & & 3.61 & 3.61 & 0.30 & & 3.57 & 3.61 & -0.75 & & 3.58 & 3.61 & -0.39 & \\
\hline & matched & 3.56 & 3.63 & -1.06 & & 3.61 & 3.65 & -0.54 & & 3.57 & 3.63 & -0.89 & & 3.58 & 3.65 & -0.81 & \\
\hline \multirow{3}{*}{$\begin{array}{l}\text { Patstock, } \\
\mathrm{t}-2\end{array}$} & unmatched & -6.97 & -7.03 & 5.80 & $* * *$ & -6.96 & -7.55 & 5.44 & $* * *$ & -6.22 & -7.69 & 8.95 & $* * *$ & -6.29 & -7.02 & 6.45 & $* * *$ \\
\hline & matched & -7.13 & -7.19 & 1.56 & & -7.06 & -6.48 & 0.77 & & -5.79 & -6.66 & 1.80 & $*$ & -6.37 & -5.68 & 1.04 & \\
\hline & & Ps R2 & LR chi2 & $p>\operatorname{ch} 2$ & $\begin{array}{r}\text { Mean } \\
\text { Bias }\end{array}$ & Ps R2 & LR chi2 & $p>\operatorname{ch} 2$ & $\begin{array}{r}\text { Mean } \\
\text { Bias }\end{array}$ & Ps R2 & LR chi2 & $p>\operatorname{ch} 2$ & $\begin{array}{r}\text { Mean } \\
\text { Bias }\end{array}$ & Ps R2 & LR chi2 & $p>\operatorname{ch} 2$ & $\begin{array}{r}\text { Mean } \\
\text { Bias }\end{array}$ \\
\hline \multirow{2}{*}{\multicolumn{2}{|c|}{$\begin{array}{l}\text { Unmatched } \\
\text { Matched }\end{array}$}} & 0.12 & 170 & 0.00 & 33 & 0.19 & 250 & 0.00 & 39 & 0.24 & 325 & 0.00 & 47 & 0.15 & 132 & 0.00 & 40 \\
\hline & & 0.03 & 18 & 0.09 & 12 & 0.05 & 20 & 0.03 & 12 & 0.05 & 28 & 0.06 & 15 & 0.04 & 12 & 0.29 & 14 \\
\hline \multirow{3}{*}{\multicolumn{2}{|c|}{$\begin{array}{l}\text { Unmatched } \\
\text { Matched }\end{array}$}} & B & $\mathrm{R}$ & $\begin{array}{r}\text { \%con- } \\
\text { cern }\end{array}$ & \%bad & B & $\mathrm{R}$ & $\begin{array}{l}\text { \%con- } \\
\text { cern }\end{array}$ & \%bad & B & $\mathrm{R}$ & $\begin{array}{l}\text { \%con- } \\
\text { cern }\end{array}$ & \%bad & B & $R$ & $\begin{array}{r}\text { \%con- } \\
\text { cern }\end{array}$ & \%bad \\
\hline & & 31 & 0.94 & 43 & 1 & 29 & 0.67 & 44 & 12 & 35 & 0.71 & 39 & 17 & 36 & 0.91 & 38 & 8 \\
\hline & & 11 & 1.17 & 32 & 0 & 14 & 0.81 & 17 & 3 & 14 & 0.99 & 23 & 1 & 13 & 1.10 & 32 & 5 \\
\hline
\end{tabular}

Note: all statistics are averages for the 14 matchings (each year of the 2001 to 2014 period) that have been performed for each type of funding.

$* * *, * *, *: p<0.01, p<0.05, p<0.1$. 
Table A4: Results of matching analysis

\begin{tabular}{|c|c|c|c|c|c|c|}
\hline Variable & Sample & Treated & Controls & Difference & S.E. & T-stat \\
\hline \multicolumn{7}{|c|}{ Regional funding } \\
\hline \multirow[t]{2}{*}{ Novel } & Unmatched & 0.0913 & 0.0384 & 0.0528 & 0.0025 & 21.22 \\
\hline & ATT & 0.0913 & 0.0658 & 0.0254 & 0.0050 & 5.05 \\
\hline \multirow[t]{2}{*}{ Increm. } & Unmatched & 0.1831 & 0.1127 & 0.0704 & 0.0038 & 18.55 \\
\hline & ATT & 0.1831 & 0.1616 & 0.0215 & 0.0066 & 3.25 \\
\hline \multirow[t]{3}{*}{ Costred. } & Unmatched & 0.0320 & 0.0211 & 0.0110 & 0.0012 & 9.13 \\
\hline & ATT & 0.0320 & 0.0256 & 0.0064 & 0.0023 & 2.86 \\
\hline & $\mathrm{N}$ & 3,116 & 22,438 & & & \\
\hline \multicolumn{7}{|c|}{ National bottom-up funding } \\
\hline \multirow[t]{2}{*}{ Novel } & Unmatched & 0.0855 & 0.0393 & 0.0461 & 0.0025 & 18.38 \\
\hline & ATT & 0.0855 & 0.0710 & 0.0145 & 0.0053 & 2.73 \\
\hline \multirow[t]{2}{*}{ Increm. } & Unmatched & 0.1887 & 0.1120 & 0.0767 & 0.0038 & 20.11 \\
\hline & ATT & 0.1887 & 0.1533 & 0.0354 & 0.0069 & 5.16 \\
\hline \multirow[t]{3}{*}{ Costred. } & Unmatched & 0.0275 & 0.0217 & 0.0058 & 0.0012 & 4.79 \\
\hline & ATT & 0.0275 & 0.0221 & 0.0054 & 0.0022 & 2.51 \\
\hline & $\mathrm{N}$ & 3,075 & 22,479 & & & \\
\hline \multicolumn{7}{|c|}{ National technology funding } \\
\hline \multirow[t]{2}{*}{ Novel } & Unmatched & 0.1144 & 0.0361 & 0.0783 & 0.0026 & 30.59 \\
\hline & ATT & 0.1144 & 0.0790 & 0.0353 & 0.0058 & 6.08 \\
\hline \multirow[t]{2}{*}{ Increm. } & Unmatched & 0.1877 & 0.1129 & 0.0748 & 0.0039 & 19.00 \\
\hline & ATT & 0.1877 & 0.1735 & 0.0142 & 0.0072 & 1.96 \\
\hline \multirow[t]{3}{*}{ Costred. } & Unmatched & 0.0318 & 0.0212 & 0.0106 & 0.0012 & 8.52 \\
\hline & ATT & 0.0318 & 0.0223 & 0.0095 & 0.0022 & 4.29 \\
\hline & $\mathrm{N}$ & 2,864 & 22,690 & & & \\
\hline \multicolumn{7}{|c|}{ European funding } \\
\hline \multirow[t]{2}{*}{ Novel } & Unmatched & 0.1063 & 0.0407 & 0.0656 & 0.0033 & 19.61 \\
\hline & ATT & 0.1063 & 0.0754 & 0.0309 & 0.0071 & 4.38 \\
\hline \multirow[t]{2}{*}{ Increm. } & Unmatched & 0.1836 & 0.1170 & 0.0666 & 0.0051 & 13.04 \\
\hline & ATT & 0.1836 & 0.1733 & 0.0103 & 0.0086 & 1.21 \\
\hline \multirow[t]{3}{*}{ Costred. } & Unmatched & 0.0302 & 0.0219 & 0.0083 & 0.0016 & 5.16 \\
\hline & ATT & 0.0302 & 0.0233 & 0.0069 & 0.0026 & 2.66 \\
\hline & $\mathrm{N}$ & 1,624 & 23,930 & & & \\
\hline
\end{tabular}

